\title{
A. van de Beek
}

\section{THE SPIRIT OF THE BODY OF CHRIST: THE HOLY SPIRIT'S INDWELLING IN THE CHURCH}

\begin{abstract}
Contrary to present-day tendencies in theology, the author argues that the church is the exclusive place of the work of the Holy Spirit, with reference to early church fathers such as Cyprian and Augustine, and to the New Testament. The Spirit is the presence of Christ who indwells his body. Therefore, the concept of social Trinity is rejected. As the Spirit of the Crucified, the Spirit displays the same strength in weakness: a pneumatologia crucis is the consequence of a christologia crucis as aspects of a theologia crucis. Specific attention is paid to I Corinthians.
\end{abstract}

\section{PRESENT-DAY PNEUMATOLOGY}

In present-day pneumatology, there is a tendency to consider the Holy Spirit as a cosmic power who indwells all beings. The Spirit gives life, future, and dynamics. The Spirit is everywhere where there is life, even in all non-living creatures. The Spirit is the creative power of God. According to some theologians, the Spirit of God is present in any event, both good and evil (see e.g., Welker 1992). To confirm this notion, such theologians can refer to the Bible, such as to the story of Saul who, according to the book of Samuel, was driven by an evil spirit of God (I Sam 16:14), or to the lying spirit in the prophets of King Ahab (I Kgs 22:22; II Chron 18:21). I must confess that I was of the same opinion (see Van de Beek 1987:210-214) until I read the early church fathers and learned from them to interpret these biblical references more critically.

Other theologians stress the positive power of the Spirit. In his book De stem van de roepende (The voice of the one who calls) (2001), the Dutch theologian Gijs Dingemans speaks about the Spirit as a voice who lures all creatures to the future, to new opportunities and to new perspectives

Dr A. van de Beek, Professor Emeritus of VU University, Amsterdam, Professor Extraordinarius at Stellenbosch University and Honorary Professor of the Sárospataki Reformed Theological Academy. E-mail: beekavd@xs4all.nl. 
of self-realisation. He borrows many of his ideas from the panentheism of the process theology of Alfred Whitehead and John Cobb. Then again, others view the Spirit especially as an inspiring power for the good and the beautiful (e.g. Lampe 1977; Bracken 1991). This is a common notion. Where people struggle for new perspectives on life, for freedom, for healing, for comfort - the Spirit of God is in them, just as in artists who are able to write or paint what goes beyond the common.

All these approaches have in common the fact that the Spirit is active anywhere in creation, not merely in the context of Christianity, or even the Church. The Spirit is not bound to the limits of the church. The Spirit is like the wind that blows where it wills and cannot be captured by borders that we can discern. The Spirit is free as God is free. This claim is often made by reference to John 3:8: "The wind blows wherever it pleases."

Although Van den Brink and Van der Kooi, in their recent handbook on Dogmatics, also refer to a broader working of the Spirit, they are much more critical than the authors referred to earlier. The Spirit who works in culture is the Spirit of the resurrected Christ. Therefore, any claim of human beings on the working of the Spirit must be critically assessed according to Christ (Van den Brink \& Van der Kooi 2012:467-474). They are closer to early Christian theology, although not as strict as the church fathers.

\section{THE SPIRIT WORKS IN THE CHURCH}

A totally different assessment is noted with regard to the church fathers. According to early Christianity, the Spirit is only present in the church. If there is a broader working of God in the world, it is not by the Spirit, but by the Logos. The latter might be in the whole of creation, because everything is created by the Logos, as John 1 mentions, or more specific in people who strive for truth, such as Socrates. ${ }^{1}$ Justin Martyr mentions that, in these instances, the Logos sows sparkles of light in the world which are derived from Christ who is the Light Himself. ${ }^{2}$ The Holy Spirit is strictly bound to the Church, not as though the Spirit were captured in the church, but because church is created wherever the Spirit works.

This has to do with the understanding of Logos and Spirit in early Christianity. Both are God's presence in the world, whereby God works in

1 Justinus Martyr, Apologia I, 46. Numbering of the chapters of the church fathers according to the translations in www.newadvent.org.

2 Apologia I, 44; II, 8 and 13. Waszink 1962 convincingly argued that "Logos spermatikos" is not about sparkles of the Logos in the world, but about the sowing Logos. 
his creation, as his two hands. ${ }^{3}$ Their working, however, is different. ${ }^{4}$ The Logos has to do with rationality and understanding of being. The meaning of the universe is related to Him. If there is any true understanding of the world, it is related to the Logos. If Greek philosophers grasp something of truth, this is understood as elements of the full truth that the Logos sows in the world. Because the meaning of creation is given in Christ, $\mathrm{He}$ is related not only to the church, but also to the entire creation, for He did not come to the handiwork of another Creator, but to his own. ${ }^{5}$ The meaning, the Logos, of the entire creation is, therefore, not different from the work of Christ.

The Spirit is not related to the basic structure of the world, but to its renewal. $\mathrm{He}$ is the dynamic power that gives ekstasis, change to a different reality. The Spirit of God is God's renewing presence in the world. Therefore, the indwelling of the Spirit cannot be separated from his work and vice versa. The work of the Spirit is due to his presence, and there is no indwelling without activity. Because of this character of true change, $\mathrm{He}$ is not related to the creation in its original being, but to the new creation, which is present in the church: "The old has gone, the new has come" (II Cor 5:17, NIV). This is the knowledge of Christ, not according to the flesh, but according to the Spirit (II Cor 5:16, ESV). This new life through the Spirit is the building of the church as the community of eternal life.

This conviction is highlighted in the struggle concerning the baptism of heretics. In the third century, the question arose as to whether heretics should be baptised or not when they came into the Orthodox Church. Leading theologians such as Cyprian of Carthage and Firmilian of Caesarea were of the opinion that they should be baptised, because the Holy Spirit does not dwell in heretic communities and thus their priests cannot legally baptise. He who does not have the Spirit cannot lend the Spirit. The Spirit is only in the Orthodox Church (see Van de Beek 2009).

It is interesting to note, in this instance, that those who do not agree with them and want to accept heretics in the church without baptising them are not of the opinion that the Spirit also dwells in heretic communities. Augustine, who accepted baptisms by heretics in the western church, argues that baptism does not belong to the church, but to Christ. $^{6}$ Therefore, any baptism in the name of Christ is valid. This seems to make room for an argument that the Spirit is also with the heretics; yet Augustine

3 Irenaeus, Adversus haereses IV, Praefatio 4 (MPG 7: 975); V,6,1 (MPG 7: 1137); V,28,4 (MPG 7: 1200).

4 Irenaeus, Epideixis $5 f$.

5 Irenaeus, Adversus haereses V,2,1; zie ook V,18,1.

6 Augustine, De Baptismo V,15,19; V,23,31. 
denies this. Although their baptism is valid, it is not effective, because they do not have the Spirit. ${ }^{7}$ "It is possible for baptism to exist without the Spirit of God." 8 Only in the community of the Catholic Church, in the presence of the Spirit, can baptism have salutary effect. ${ }^{9}$

The Creed shows how strictly the Spirit and the church are mutually connected according to early Christianity: ${ }^{10}$ "We believe in one God, the Father, ... and in one Lord, Jesus Christ, ... and in ...". We would expect "in one Holy Spirit", but the word "one" is omitted. It is merely "and in the Holy Spirit". This does not mean that the Holy Spirit does not belong to the unity of the one God. The Creed only clarifies where and how the Spirit belongs to it, namely in the Church. The Creed continues: "and in one holy catholic and apostolic Church". We believe in the one Church. In the Church, the presence of God as the Triune is visible as it was previously visible in the bodily presence of Jesus. As his physical body ascended to heaven, his body on earth is the church where his Spirit dwells. There is no salvation outside this church, for it is only the Spirit who gives life. ${ }^{11}$

It is from this critical perspective that I read the famous text about the Spirit who blows like the wind. The common opinion is that it is about the Spirit, indeed. However, it is not about the Spirit, but about the believer: "The wind blows wherever it pleases. You hear the sound, but you cannot tell where it comes from or where it is going. So it is with everyone born of the Spirit" (Jn 3:8). It is not about the Spirit, but about those who are born from the Spirit: those who believe (cf. 1:12v). One cannot go back to the beginnings of believing. Such intimations are not based on rational arguments, but are given by God. It is not about the Spirit who goes anywhere, but it concerns the birth of God's children. Their believing in the Son of God is not because of their own rational decision, but is thanks to God's incomprehensibility. The verse does not speak about a free blowing Spirit in the cosmos and the world, but about the foundation of the church. It is not a human institution, but new creation in the Spirit.

7 Augustine, De Baptismo V,23,33.

8 Augustine, De Baptismo V,24,34.

9 Augustine, De baptismo V, 7-9.

10 Denziger 150.

11 Cyprian, Ep. 72,21. "If the Church is not with heretics, therefore, because it is one, and cannot be divided; and if thus, the Holy Spirit is not there, because $\mathrm{He}$ is one, and cannot be among profane persons, and those who are without; certainly also baptism, which consists in the same unity, cannot be among heretics, because it can neither be separated from the Church nor from the Holy Spirit” (Cyprian, Ep. 73,4) 
The book of Acts is the book of the Spirit. It begins with Pentecost and tells how the Spirit works in the world. This is the book of the Church. The Spirit is there where people believe and enter the church by being baptised (Acts 2:38-42). The relation of the Spirit and the church is so close that a decision of a meeting of church leaders can be announced by the phrase: "It seemed good to the Holy Spirit and to us ..." (Acts 15:28). Because the church decided to make some rules for the behaviour of Christians from the gentiles it is the Holy Spirit who decided so.

Other agreements were made at the Jerusalem conference. Paul would become the apostle of the gentiles, whereas Peter would go to the Jews (Gal 2:7-9). After the conference, Paul resumes his missionary activities in the present Turkey. After visiting the congregations which he founded on his first travel, he wants to go to Asia, but "Paul and his companions traveled throughout the region of Phrygia and Galatia, having been kept by the Holy Spirit from preaching the word in the province of Asia" (Acts 16:6). Then he turns north and "they tried to enter Bithynia, but the Spirit of Jesus would not allow them" (Acts 16:7). There are different suggestions concerning the meaning that the Spirit did not allow them to go to Asia and Bithynia. It was mainly "eine innere Stimme" (Zahn 1921:560). The meaning becomes clear against the backdrop of the previous chapter. There were large Jewish communities in both Asia and Bithynia. Going there would imply going to the Jews (Breytenbach 2012). However, that would not be in accordance with the agreements made at the Jerusalem meeting. Thus Paul takes another route. It was a decision of the church that Paul would go to the gentiles and, because it is a decision of the church, it is a decision of the Spirit. Due to the agreement of the church, the Holy Spirit kept him from preaching the gospel in Asia and Bithynia. If we consider the tone of Paul's letter to the Galatians, we must conclude that it was a wise decision not to send Paul to the Jews and because of this Peter sent his wonderful letter to the Christians in Asia and Bithynia (I Peter 1:1). Paul's letter to the Galatians would have raised considerable conflicts in those communities. ${ }^{12}$

\section{THE SPIRIT OF CHRIST}

According to the Gospel of John, the Spirit is another presence of God after Christ left the world. After his death and resurrection, Christ ascended to heaven, and He promised another Counselor, a Paraclete whom the Father would send. The Spirit will be with them until the consummation of the world, as Jesus promised to be with them. Thus the Spirit is God's

12 It is clear, of course, that this argument supports the South-Galatian hypothesis. 
personal presence in the Church, as Jesus was God's personal presence during his earthly life. Because it is one and the same God, there cannot be two presences: "as long as I am with you the Counselor cannot come", says Jesus (16:7). Therefore, it is good that He leaves, for the Spirit will make human beings members of the body of Christ, so that they may participate in eternal life. The Spirit of life makes them participate even in the divine nature (II Peter 1:4).

Thus the Spirit is another way of God's presence than God's incarnation in Christ. There is a tendency in twentieth-century theology to stress the difference. The Son and the Spirit are two and we should, therefore, not concentrate the whole theology in Christ. There is not only the Son, but also the Spirit and the Father. As a consequence of this approach, the persons of the Trinity are stressed in their diversity. Many theologians consider Trinity as a social Trinity: a community of love, as the ground of community in the church, among people and in the whole creation. The cosmos can only exist in community, and people in the church are called to contribute to this community. The notion of a social Trinity is derived from the theology of the Cappadocian theologians at the end of the fourth century who also emphasise the cooperation of different persons in the divine being. Recently, the theologian Colin Gunton took this line of thought (see especially Gunton 1993; 2003). He traces it back to as early as Irenaeus at the end of the second century. Irenaeus mentions that the Son and the Spirit are the hands of God whereby God acts. ${ }^{13}$ Gunton argues as follows: whereas God has two hands, we should distinguish between his different activities: God acts not only by the Son, but also by the Spirit (1992:79; 1998:53; 2003:77). We should pay attention not only to Christ, but also to the Spirit. There is a difference in activities (1993:54).
Creation is for [Irenaeus] achieved through the instrumentality of the Son and the Spirit, the 'two hands' of God, by the form of whose agency an unrelational individualism of will is ruled out. The will of God is realized through a kind of community of love (Gunton 1993:120).

In this instance, a further step is made into the doctrine of Trinity. The Cappadocians stressed community of the three divine persons. This is reflected in the Eastern Orthodox traditions, where unity is dominant as a unity of divine power, with the patriarch and the emperor (or his successor in present-day presidents) as the cooperating representatives of the heavenly Father. Gunton stresses diversity. His predecessor, the Dutch theologian Arnold van Ruler, does not tire of saying that there is not

13 Irenaeus, Adv. Haereses IV, Praef. 4; V,6,1; V,28,4. 
only Christ, but also the Father as the Creator and the Spirit who is active in the world (see especially Van Ruler 1969:176f.; Van 't Kruis 1997). The work of the Spirit is not restricted to atonement, as Christ's work is, but it comprehends the whole of life, from infants to the politics of states (Van Ruler 1973:31).

This is in line with the western version of the Nicene Creed where it is confessed, as far as the Spirit is concerned, that the Spirit proceeds from the Father and the Son. "[A]nd the Son" - filioque - is one of the main differences between East and West. The East keeps to unity even in the diversity of individuals. The West prefers distinction. One must distinguish between the Spirit's acting as implementation of the work of the Son in salvation, and his acting as the Spirit of the Father in creation. The West prefers distinctions: creation and salvation, nature and grace, church and state. There is always a conjunctive "and".

By this emphasis on the distinct work of the Spirit in creation, the Spirit's presence is not limited to the church. There is a wide field of divine presence in the Spirit outside the church. What began in the gospel of John as a different presence of the same God becomes a competition of activities of two divine persons - a Holy Spirit with a Janus head. The Spirit works in the church, on the one hand, and in state and society, on the other, and both are never fully compatible.

In considering the beginnings of Christian theology, we find a different perspective. On several occasions, Irenaeus mentions the Son and the Spirit as the two hands of God. However, in each instance it is about the two hands doing the same work. God uses both hands to create the world..$^{14}$ If we want to do a good job, we do so with both hands. If our two hands do different tasks, both will fail. That is precisely the very point of Irenaeus: the Son and the Spirit do one and the same work of God; therefore, it becomes perfect..$^{15}$ It is the perfection of the unity of creation and salvation, ${ }^{16}$ of creation and glorification. ${ }^{17}$

This is in line with the gospel of John, in whose tradition Irenaeus lived. According to John, Jesus states the following about the Spirit: "He will not speak on his own. He will speak only what He hears. All what belongs to the father is mine. That is why I said the Spirit will take from what is mine and make it known to you" (Jn 16:15). The Spirit makes people participate in the work of Christ. Not only John speaks about the Spirit in that way,

14 Irenaeus, Adv. Haereses V,1,3.

15 Irenaeus, Adv. Haereses V,6,1.

16 Irenaeus, Adv. Haereses IV, Praef. 4.

17 Irenaeus, Adv. Haereses V,5,1. 
but also all of the New Testament authors. According to the synoptic gospels, the Spirit is upon Christ when He does his work on earth (Mt 3:16; 4:1; 12:18; Mk 1:10, 12; Lk 3:22; 4:1, 18), and it is the Spirit of Christ who inspires the members of the Church (Mt 3:11; 10:20; Mk 1:8; 13:11; Lk 3:16; 12:12). Both belong intrinsically together. They are one and the same God in action. Now that Christ is in heaven, his Spirit is his own presence on earth and we must view the Spirit in this perspective: no pneumatology without Christology and no pneumatology that is not in Christological perspective. That is the way of thinking about the Holy Spirit of both the New Testament and Christian theologians of the first centuries.

\section{THE SPIRIT OF THE CRUCIFIED}

The Spirit is the Spirit of Christ. This means the Spirit of the Crucified. Jesus's promises of the Spirit in the gospel of John are given in the perspective of his death on the cross. It is this Spirit that is given on Pentecost, and the book of Acts has no other paradigm. When the Spirit is poured out on the apostles, they start preaching, and the climax of the very first sermon in the church that sets the tone for all further preaching is "this Jesus whom you crucified" (Acts 2:36). That is the focus of the Spirit's work in the world: confronting people with Jesus and Him crucified. The people in Jerusalem were perturbed by this confrontation. Many of them were converted - and many of them revolted against this message, as indicated in the subsequent chapters. Both the religious and the political leaders revolted.

In the gospel of John, Jesus points to this confrontation in his teaching of the disciples: "When the Spirit will come He will convict the world of guilt in regard to sin and righteousness and judgment" (Jn 16:8). I felt the full meaning of this in an airport in Greece. We had to go through the elegchos asphaleias, the security check. I noticed that this is the word the gospel uses for "convict", elegcho. Thus you can read it as: He will check the world on sin, righteousness and judgement. The Spirit says to the world: "Please open your luggage. What is in it? Is there any sin?" Some people already confessed their sin, because they believe in Jesus. However, those who did not believe and hid their sins are now unmasked. They are unmasked of sin, because they did not believe in the one born Son of God. They denied their sins, because they deny the Son. They deny God's own judgement, who sent his Son for the sin of the world. If we mention that we do not have sins, we make God a liar, for He sent his Son for the atonement of $\sin (\mathrm{In} 1: 10)$. If we do not have sin, this account is pure nonsense. 
Where the Spirit of Christ comes, our lives are confronted with Christ and Him crucified; whoever does not believe in the Son has already been condemned because of this un-believing, according to John (3:18). The focus of the work of the Spirit is unmasking the world in its sin. The only salvation is to believe in the Son who has been crucified. That is the end of any hope based on ourselves. We can only live by accepting the death on his cross, which is our own death. It is from this death that Jesus rose, and those who become members of his body by baptism will be saved in a new life. That is Peter's answer to the dismayed people on Pentecost: "Repent and be baptized" (Acts 2:38).

If the Spirit of the crucified Christ is in us, we become humble people. It is we who crucified Him by our sins and it is only his grace that saved us. That is the outcome of the unmasking work of the Spirit. Christ gave Himself for us while we were still sinners (Rom 5:8), even enemies (Rom 5:10). This acknowledgement makes people be and act differently. The way they think and decide is within this paradigm: being in Christ. They are always aware of his willingness to make Himself as nothing, becoming obedient unto death, even the death on the cross (Phil 2:8), as a cursed person on behalf of us (Gal 3:13). They come to Jesus with this outlook, in ultimate gratefulness. They approach other people with this attitude: brothers and sisters in Christ who can only live through the same grace. With this attitude they approach the people outside of this relationship: those who deny God's indescribable gift in Christ and who believe that they are free from any sin. Those people are strong in the world. They are not meek in their opinions in the manner that Christians are. Christians are humble and all wet, befitting their baptism; the world is strong and confident in its stance. Early Christians walked softly, indeed, and are thus vulnerable. They had compassion with the victims of history, the outcasts, the orphans, the handicapped, and the diseased. They confronted the world with another way of life. By doing so, they unmasked the world in its harshness, its violence, its self-satisfaction.

The Spirit works in and through the church and it is through the church that the Spirit unmasks the world. In line with that first sermon of Peter on Pentecost, such revealing is done by the preaching of the church. It is also brought to light by the life of the church in the compassion for the weak. ${ }^{18}$ The old world dislikes this unmasking work of the Spirit and, therefore, it persecutes the people in whom the Spirit dwells by any means at their disposal, from cultural exclusion to the stake and the lions. It is as Jesus

18 Athenagoras, Legatio pro Christianis 11; 32-35; Justinus Martyr, Apologian I,16; Ad Diognetum 5. See Meijering 2004:177-204. 
said: "In the world you will have trouble. But take heart, I have overcome the world" (Jn 16:33)

In this context, we must reconsider the meaning of "Paraclete". This term is usually translated as "Counselor". In the juridical language field that John uses in chapter 16 (guilt, righteousness, judgement, condemnation, truth), the juridical meaning of Paraclete is more apt. It means "lawyer". The Holy Spirit is the lawyer of those in the world who do not have a helper. This advocate enters the court case on behalf of them and accuses the world of its behaviour - unmasking it of its guilt and sin. The Holy Spirit enters pleas for us as the most skillful lawyer before the only trustworthy judge: God in heaven. He is the Spirit of truth (Jn 14:17; 15:26; 16:13) - a Spirit that the world does not know (Jn 14:17), but He knows the world well and will convict it.

\section{THE SPIRIT'S ACTIVITIES IN THE CHURCH ACCORDING TO I CORINTHIANS}

Many people refer especially to I Corinthians as being about the Holy Spirit. This is correct, although they could refer to any book in the Bible. For, according to the Creed, the Holy Spirit spoke through the prophets. Nevertheless, I Corinthians can help shape our understanding of what the presence of the Spirit implies. Often people restrict themselves to Chapters 12 and 14 if it is about the Spirit in I Corinthians. Then, however, we miss the line of the argument. Paul begins with the unity of the church (1:10-16). As he says in the section that deals explicitly with the Spirit, it cannot be divided, for all Christians are baptised in one Spirit (12:13). There is one baptism just as there is one Spirit and one Lord. Therefore, baptism is not an isolated event of making proselytes by church planters - as Paul argues in Chapter 1 - but baptism is one of the elements that constitute the fullness of life in the Spirit of Christ. The basis of this is the foolishness of the preaching of Christ and Him crucified, according to Paul (2:2). Those who are in Christ live according to this message: in love and faithfulness to each other, always willing to give up their own longings on behalf of the other ones. "If what I eat causes my brother to fall into sin, I will never eat meat again!" (I Cor 8:13). Christian life is life for all in communion with its centre in the Lord's Supper in remembrance of his death, where they confess: "Jesus is Lord" (12:3). Paul brings this profession to his explicit discourse on the Spirit. For it is the Spirit of Christ that makes the apostle preach about the Christians loving and celebrating the Eucharist (I Cor 11). It is within this communion of the Spirit that his wonderful gifts such as healing, glossolalia and prophecy are given. These are not isolated gifts 
of outstanding Christians, but gifts by the Spirit for the edification of the church. They are not for the glory of those who express them, but for the glory of God and the service of his people, to build up the church (14:12). "Everything must be done so that the church may be built up" (14:26). That is the aim of the work of the Spirit. We must note that the chapters on such gifts follow the chapters on the Lord's Supper. They must be read in this perspective: as gifts to the celebrating community that is remembering the death of Christ for them. At the core of the presence of the Spirit are not the gifts, but the liturgy. In celebrating the liturgy, the church is the body of Christ and the place where his Spirit dwells. In this liturgy, he bestows the church with special gifts, not necessary but as free grace, a wonderful gift to be thankful for. And in the centre of all these gifts is the love, as Chapter 13 is in between Chapters 12 and 14: the special gifts are the outside of the kernel that is love - eternal love that persists when prophesies and tongues will have disappeared. This love continues in the life of resurrection (see Chapter 15).

The work of the Spirit, according to I Corinthians, is preaching Christ and him crucified, resulting in baptism and a life of service, concentrated in the celebration of the Eucharist, where sometimes the Spirit gives expressions of special grace and everything is concentrated in true love that is the beginning of eternal life.

This picture does not differ from the book of Acts, the other book of the New Testament that pays specific and explicit attention to the Spirit. Acts is written in the perspective of the Holy Spirit who is poured out at Pentecost. This book describes the Spirit's activities in the world, now that the real presence has been given to the world. The main activity that Acts describes is preaching - preaching not about the Spirit, but about Jesus. The effect is a community of people who are baptised, who break the bread, who share their goods, where wonderful healings and spiritual gifts occur, and who are able to accept each other's differences, even the greatest difference in the world: between circumcised and not circumcised. This community is the result of the eschatological outpouring of the Spirit. This community is the eschatological reality of eternal life - the new creation according to Paul (II Cor 5:17). It is the creation of the Spirit, strangers and resident aliens in the world, but living as the visible body of Christ wherein his own Spirit is life-giving reality.

\section{PNEUMATOLOGIA CRUCIS}

The church is the dwelling place of the Spirit. She is the visible body of Christ in the world as the visible result of the activities of his Spirit. 
How can we say this if we view the real church? It is an aggregation of competing denominations. It is a place where priests abuse young children. It is a place of exclusion and discrimination. It is a place ... How can we claim that the church is the visible result of the activities of the Holy Spirit? The Holy Spirit! Is this not devoid of any sense of reality?

A counter question is essential. Jesus is the visible presence of God in the world. How can you say that? He is a man of past times who did not know anything about modern physics and communication. He is a man who was so passionate that in the temple court he smashed tables of moneychangers and overturned the seats of the pigeon sellers. He was so anxious about dying that his sweat became bloody. He was condemned as a criminal and executed and he did not stoically endure his punishment like Socrates. Instead, he died crying out (Mk 15:37). This is the visibility of God in the world. Is it? If not, Christian faith is a lie. If so, people must accept this strange God in this strange community called Church.

God is in the world as the crucified one. This is applicable not only to Jesus, but also to the Spirit, for He is the Spirit of the crucified. Just as we cannot do without a theology crucis we cannot do without a pneumatologia crucis. For the Spirit is today's presence of God.

Is it thus acceptable that the church is such a body without beauty or majesty, despised and rejected due to her own failures? Shall Christians keep to their divisions, their exclusions, their abuses? The answer is easy and does not differ from Paul's answer to the question: "Shall we go on sinning so that grace may increase? By no means!" (Rom 6:1v). We live by the Spirit of love, the Spirit of the one God, who reconciled the world. How shall we live in exclusion, in disunity, in abuse and hatred?

Christians are called to celebrate the Eucharist, in memory of the death of Christ. That is the place where the Holy Spirit bestows them with his gifts, love. This will change their life.

\section{BIBLIOGRAPHY}

Augustine

De Baptismo, MPL 43:107-244.

BRACKEN, J.A.

1991. Society and Spirit: a Trinitarian cosmology, Cranbury/London/Mississauga:

Associated University Press. 
BreytenBach, C.

2012. 'What happened to the Galatian Christians? Paul's legacy in southern Galatia'. Paper at the Conference on the Letter to the Galatians, Faculty of Theology, University of the Free State, Bloemfontein, 13-14 March 2012.

Dingemans, G.D.J.

2001. De stem van de roepende: Pneumatheologie. (3de druk). Kampen: Kok.

Gunton, C.E.

1992. Christ and creation. The Didsbury Lectures. Waynesboro: Paternoster Press.

1993. The one, the three and the many: God, creation and the culture of modernity. Cambridge: Cambridge University Press.

1998. The triune creator: A historical and systematic study. Edinburgh Studies in Constructive Theology. Edinburgh: University Press.

2003. Father, Son, and Holy Spirit: Essays toward a fully Trinitarian theology. London/New York: T. \& T. Clark.

IRENAEUS

Adv. Haereses, MPG 7:437-1224.

Epideixis, SC 406.

JustinUs MARTYR

Apologia I, MPG 6:327-442.

LAMPE, G.W.H.

1977. God as Spirit. Bampton Lectures 1976. Oxford: Clarendon Press.

MEIJERING, E.P.

2004. Geschiedenis van het vroege Christendom: Van de Jood Jezus van Nazaret tot de Romeinse keizer Constantijn. Amsterdam: Balans.

Van de Beek, A. 1987. De adem van God: De Heilige Geest in kerk en kosmos. Nijkerk: Callenbach. 2009. Heretical baptism in debate. In die Skriflig 43(3):537-561.

VAn den Brink, G. \& VAn der Kool, C.

2012. Christelijke dogmatiek: een inleiding. Zoetermeer: Boekencentrum.

VAN RULer, A.A.

1969. Theologisch werk I. Nijkerk: Callenbach.

1973. Theologisch werk VI. Nijkerk: Callenbach.

VAN 'T KRUIS, J.M.

1997. De Geest als missionaire beweging: Een onderzoek naar de functie en toereikendheid van gereformeerde theologie in de huidige missiologische discussie. Zoetermeer: Boekencentrum. 
WASZINK, J.H.

1962. Bemerkungen zu Justins Lehre vom Logos Spermatikos. In: A. Herman \& A Stuiber (Hrsg.). Mullus: Festschrift Theodor Klauser. Jahrbuch für Antike und Christentum. Ergänzungsband 1, (Münster: Aschendorffsche Verlagsbuchhandlung), pp.380-390.

WELKER, M.

1992. Gottes Geist: Theologie des Heiligen Geistes. Neukirchen-Vluyn: Neukirchener Verlag.

ZAHN, T.H.

1921. Die Apostelgeschichte des Lucas. Leipzig/Erlangen: Deichertsche Verlagsbuchhandlung.

Keywords

Holy Spirit

Church

Trinity

Pneumatology
Trefwoorde

Heilige Gees

Kerk

Drie-eenheid

Pneumatologie 